\title{
Burnout Levels and Knowledge Analysis Regarding Burnout Prevention During Work from Home in Young Adults
}

\author{
Hanifah Nabilaha, Annisya Adinda Febriyantia, Azalia Monica Michaela ${ }^{a}$, Dewi Ratna \\ Sari ${ }^{\mathrm{b}}$
}

${ }^{a}$ Faculty of Medicine, Universitas Airlangga

${ }^{2}$ Department of Anatomy, Histology, and Pharmacology, Faculty of Medicine, Universitas Airlangga

e-mail: dewi-r-s@fk.unair.ac.id

\begin{abstract}
Background: COVID-19 pandemic that has been continuing for 1.5 years has affected the psychological condition of Indonesian people, one of which is severe stress triggered by work or better known as Burnout Syndrome which if it occurs continuously will affect physical and mental health. This condition has a direct impact on health workers, students, employees, especially those who must keep Working from Home (WFH). Therefore, knowledge of productive activities is required to prevent burnout during work from home.

Objective: To analyse the knowledge about burnout prevention, the burnout levels and the correlation between work and burnout levels on young adult webinar participants.

Methods: This research was descriptive analytics using MBI-GS questionnaires to measure burnout levels, and also using pre-test and post-test about maintaining productivity and preventing burnout during COVID-19 pandemic. Questionnaires were distributed through google forms, before and after the online delivery of materials at SEROTONIN 2021 webinar event. The data were analysed by paired t-test and Chi-square test using IBM SPSS version 23.

Results: Total of 163 who filled out MBI-GS questionnaires as well as 51 participants filled the pre-test and post-test questionnaires, with an age range of 18-40 years, most of them were college students. There was a significant increase in knowledge by $16.93 \%$ from average score of 56.13 to 65.63 ( $\mathrm{p}=0.028$ ). About $55.22 \%$ of participants experienced high burnout levels, and $27 \%$ of participants experienced very high burnout levels. It was found that there was no correlation between occupation and participant's burnout levels $(\mathrm{p}=0.236)$.

Conclusion: Educational information delivered through webinar can increase the young adult's knowledge on burnout prevention during WFH. Most of the participants experienced high and very high levels of burnout. However, there was no correlation between the occupation and the burnout level of the participants.
\end{abstract}

Keywords: Burnout; COVID-19; Mental health; Work from home

\section{Introduction}

Coronavirus Disease 2019 (COVID-19) which has become a pandemic in many countries around the world, is an infectious disease caused by one type of virus group, namely the coronavirus which was newly discovered in December 2019 in Wuhan, China [1]. The Task Force for Handling COVID-19 (Satuan Petugas / Satgas COVID-19) reported that currently in July 2021 in Indonesia, there were 3,127,826 confirmed cases of COVID-19 of which around $79 \%$ of cases had recovered and $18.4 \%$ of active cases followed by $2.6 \%$ of cases died [2]. This viral infection is believed to be transmitted through aerosols and/or droplets, one example being sneezing and dry coughing from a COVID-19 patient can produce viral clumps with thousands of droplets per cubic centi-meter [3]. Therefore, several ways to reduce the risk of being infected and stop the spread of COVID-19 are frequently wash hands, use masks, maintain a distance of at least 1 meter, and avoid crowded places, especially by staying at home for self-isolation [1].

Currently, the government has declared the implementation of emergency community activity restrictions or known as Pemberlakuan Pembatasan Kegiatan Masyarakat (PPKM), especially in the areas of Java and Bali. During PPKM, almost all social activities are temporarily closed while teaching and learning activities as well as offices / workplaces are carried out 100\% online or work from home (WFH) [4]. According to research, it was found that working from home can create more stress and result in more fatigue [5].

Burnout is a state of emotional, physical, and mental exhaustion caused by excessive and prolonged stress [6]. Burnout during a pandemic can drain many aspects of life such as exhaustion both energy and emotional. This can reduce motivation and cause feelings of helplessness, hopelessness, and irritability, especially during social isolation, high levels of prolonged stress due to lack of opportunity to perform simple tasks in normal life [6]. Study conducted by a research team from the Master of Occupational Medicine Faculty of Medicine, Universitas Indonesia reported that $83 \%$ of health workers in Indonesia experience burnout syndrome moderate and severe, which is psychologically at risk of disrupting quality of life and work productivity in health services [7]. According to the Management 
development assistance survey, around $80 \%$ of workers have shown symptoms of stress because they worried about their health conditions [8]. The results of the literature evaluation obtained from 10 journals summarized that college students in Indonesia who conduct distance lectures experienced stress with a percentage of $55.1 \%$ and anxiety around $40 \%$ [9]. Therefore, there are many efforts that can be done to reduce stress during the pandemic, including by interacting with friends online. In addition, one way to deal with stress is to do me time, which means spending time alone but still being productive and fun, by doing hobbies or looking for other productive entertainment [10].

Knowledge about maintaining productivity and avoiding burnout during WFH during COVID-19 pandemic is highly needed by the community, especially young adults. This study aims were to analyse the knowledge of young adults regarding the prevention of burnout, the level of burnout and the relationship between occupation and the level of burnout.

\section{Methods}

This research is a descriptive analytic study on participants aged 18-40 years (young adults) using a questionnaire via google-form distributed before and after the presentation of material at the webinar event with the title of Strive Towards Exceptional Physical Wellbeing in Pandemic Situation (SEROTONIN) 2021. The questionnaire consists of a pre-test and post-test on maintaining productivity and avoiding burnout during WFH to measure the level of knowledge before and after giving the material and the Maslach Burnout Inventory General Survey (MBI-GS) questionnaire to measure the burnout levels [11].

The inclusion criteria were participants aged 18-40 years who attended the webinar and filled out the pre-test and post-test questionnaires as well as the MBI-GS questionnaire and the exclusion criteria were participants aged $<18$ years or $>40$ years and participants who did not fill out the questionnaire completely. The pre-test and post-test questionnaires consist of 8 multiple choice questions that have passed the validity and reliability tests. The MBI-GS questionnaire consists of 22 statements with a scale of 0-6 to measure the respondents' perceptions of the statements given. This questionnaire measures the burnout's level of participants through statements that represent 3 dimensions of burnout, there were 9 statements that represented emotional exhaustion, 5 statements that represented the dimension of depersonalization, and 8 statements that represented the dimensions of decreasing personal achievement. The MBIGS questionnaire has passed the validity and reliability tests according to previous research conducted by Purwanto (2019) [12]. The total score range 0-132 was categorized into four levels of burnout with very low (0-33), low (34$66)$, high (67-99), and very high (100-132) [11].

Information regarding the implementation of the webinar is disseminated through social media like Instagram and webinars are carried out through Zoom Meetings that was held in July 2021. The data obtained, processed and analyzed using IBM SPSS 23 and presented in the form of tables and bar charts. Calculation of data were shown in the form of frequency and percentage for burnout levels, as well as mean for pre-test and post-test results. The Wilcoxon Signed Rank Test was used to compare the average knowledge at the pre-test and post-test due to the abnormal distribution of the data. The Chi-Square test was used to see the relationship between work and burnout levels.

\section{Results}

Number of participants who participated in the webinar was 223 participants with 51 participants met the inclusion criteria. The distribution of participants by age and occupation was presented in table 1 .

Table 1. Distribution of participants by age and occupation $(\mathrm{N}=51)$.

\begin{tabular}{cc}
\hline \multicolumn{1}{c}{ Demographic characteristics } & $\mathrm{n}(\%)$ \\
\hline 18-25 Years & $49(96.08 \%)$ \\
$>25$ Years & $2(3.92 \%)$ \\
Occupation & \\
Student & $1(1.96 \%)$ \\
College Student & $45(88.24 \%)$ \\
Employee & $3(5.88 \%)$ \\
Unemployment & $2(3.92 \%)$ \\
\hline
\end{tabular}

Most of the participants were included in the age range of 18-25 years, and the majority came from college students due to one of the promotion accounts that used was specifically promoted campus activities. 
Table 2. The questions with the number (percentage) of correct answers in pre-test and post-test $(\mathrm{N}=51)$.

\begin{tabular}{|c|c|c|c|}
\hline No & Questions & Pre-test & Post-test \\
\hline 1. & Burnout can be defined as... & $27(52.9 \%)$ & $33(64.71 \%)$ \\
\hline 2. & $\begin{array}{l}\text { During burnout, a person can experience any of the following, } \\
\text { except... }\end{array}$ & $39(76.5 \%)$ & $44(86.27 \%)$ \\
\hline 3. & $\begin{array}{l}\text { Emotional symptoms that can be experienced by someone when } \\
\text { burnout is... }\end{array}$ & $14(27.5 \%)$ & $24(47.06 \%)$ \\
\hline 4. & $\begin{array}{l}\text { The following behaviour that can appear in someone who } \\
\text { experiences burnout is... }\end{array}$ & $21(41.2 \%)$ & $25(49.02 \%)$ \\
\hline 5. & The following solution(s) to overcome burnout is/are... & $26(51 \%)$ & $29(56.86 \%)$ \\
\hline 6. & The way to overcome boredom while working from home is... & $36(70.6 \%)$ & $39(76.47 \%)$ \\
\hline 7. & The benefits of working from home are... & $42(82.4 \%)$ & $47(92.16 \%)$ \\
\hline 8. & $\begin{array}{l}\text { The complaint(s) that can be found during working from home } \\
\text { is/are... }\end{array}$ & $24(47.1 \%)$ & $32(62.75 \%)$ \\
\hline
\end{tabular}

The table 2 showed that there were increased of correct answers in all questions. The largest increase of correct answer can be seen in question number 3 . Whereas, the question with the smallest percentage of increasing was number 6 , which was $4.4 \%$

Table 3. Analysis of pre-test and post-test regarding burnout with Wilcoxon Signed Rank Test $(\mathrm{N}=51)$.

\begin{tabular}{ccccc}
\hline Knowledge & Mean \pm SD & Minimum & Maximum & P -value \\
\hline Pre-test & $56.13 \pm 24.03$ & 12.50 & 100.00 & \multirow{2}{*}{$0.028^{*}$} \\
Post-test & $65.63 \pm 20.69$ & 12.50 & 100.00 & \\
\hline
\end{tabular}

*Significant if $\mathrm{p}<0.05$.

Based on table 3, there was significant difference between mean scores of pre-test and post-test, by increasing the percentage of $16.93 \%$. Twenty-eight participants $(54.90 \%)$ got an improvement in their score after attending the webinar. Meanwhile, 16 participants $(31.37 \%)$ had no improvement in their score and 7 (13.73\%) participant got lower post-test score compared to their pre-test after attending the webinar.

Two hundred and thirty-one webinar participants filled out the MBI-GS questionnaire, and only 163 participants met the criteria. The distribution of participants who filled out the MBI-GS questionnaire by age and occupation were listed in table 4.

Table 4. Distribution of participants by age and occupation $(\mathrm{N}=163)$.

\begin{tabular}{lc}
\hline \multicolumn{1}{c}{ Demographic characteristics } & $\mathrm{n}(\%)$ \\
\hline Age & \\
18-25 Years & $157(96.3 \%)$ \\
> 25 Years & $4(2.5 \%)$ \\
36-40 Years & $2(1.2 \%)$ \\
Occupation & \\
Student & $10(6.1 \%)$ \\
College student & $139(85.3 \%)$ \\
Employee & $8(4.9 \%)$ \\
Unemployment & $6(3.7 \%)$ \\
\hline
\end{tabular}

The majority of participants who met the inclusion criteria were in the age range of 18-25 years and were dominated by college students due to the webinar promotion media accounts were particularly informs about campus activities. 
Table 5. Burnout levels of participants using the MBI-GS questionnaire (N=163).

\begin{tabular}{ccccc} 
Burnout levels & $\mathrm{n}$ & Mean $\pm \mathrm{SD}$ & Minimum & Maximum \\
\hline Very Low & 3 & $28.67 \pm 3.05$ & 26.00 & 32.00 \\
Low & 26 & $59.08 \pm 5.90$ & 46.00 & 66.00 \\
High & 90 & $82.22 \pm 9.52$ & 67.00 & 99.00 \\
Very High & 44 & $109.50 \pm 8.81$ & 100.00 & 132.00 \\
\hline
\end{tabular}

Table 5 indicated the burnout levels of participants using the MBI-GS questionnaire. The total average of the burnout level was $84.90 \pm 20.24$. Based on the classification of burnout levels by Maslach, Jackson, \& Leiter (1997) the average score of the total MBI-GS was in the category of high burnout levels. The majority of participants experienced high and very high burnout levels $(82.21 \%)$ [11].

Table 6. The analysis of the relationship between occupation and burnout levels participants by Chi-Square Test $(\mathrm{N}=163)$.

\begin{tabular}{|c|c|c|c|c|c|c|}
\hline \multirow{2}{*}{ Occupation } & \multicolumn{4}{|c|}{ Burnout Levels } & \multirow{2}{*}{$\mathrm{n}$} & \multirow{2}{*}{ P-value } \\
\hline & Very Low & Low & High & Very High & & \\
\hline Student & 0 & $1(10 \%)$ & $5(50 \%)$ & $4(40 \%)$ & 10 & \\
\hline College Student & $3(2.16 \%)$ & $24(17.27 \%)$ & $77(55.39 \%)$ & $35(25.18 \%)$ & 139 & \\
\hline Employee & 0 & $1(12.5 \%)$ & $2(25 \%)$ & $5(62.5 \%)$ & 8 & 0.236 \\
\hline Unemployment & 0 & 0 & $6(100 \%)$ & 0 & 6 & \\
\hline Total & 3 & 26 & 90 & 44 & 163 & \\
\hline
\end{tabular}

* Significant if $\mathrm{p}<0.05$

Table 6 showed that there was no relationship between occupation and burnout levels. College student was the group with highest level of burnout with $55.39 \%$ and $25.18 \%$ participants suffered from high and very high burnout levels, respectively.

\section{Discussion}

Result of this study shows that large number of participants experiencing high levels and very high levels of burnout during the pandemic. In line with this results, Christiana (2020) mentioned that high level of burnout can be caused by several factors such as isolation, work overload, lack of social support, and an inadequate reward system [13]. These factors are further strengthened by situations work from home where interaction with co-workers is reduced and people have to do their work in new situations. In addition, the number of participants where the majority are college students also affects the results of the study. Based on previous research, it was reported that the incidence of academic burnout increased in pandemic conditions [14]. Academic burnout is a condition that afflicts students and college students where they feel tired, cynical, and stay away from all academic activities [15].

There are several factors that can affect a person's knowledge, include age, education, knowledge, environment, socio-culture, and research methods [16]. Based on this theory, the increase of knowledge in this research can be caused by the majority of participants were at the college students. Age can also be a factor in increasing knowledge where late teens (19-21 years) have mental and emotional maturity that supports the process of absorbing information more easily [17]. In addition, the increase in knowledge in this study can also be caused by the educational method provided, where this webinar is an audio-visual education method because participants can see and listen to explanations from resource persons, besides that the webinar becomes interactive by holding a questions and answer session at the end of the material so that it can improve knowledge of participants significantly [18].

There was no correlation between occupation and burnout levels in this research. This result might be caused by the uneven distribution of the participants occupation which dominated by the college students. Another thing that can affect the results of the work relationship with the burnout level is that the workload of a job, it can be interpreted that the greater the workload of a job, the higher the level burnout of the job [19]. If a group of jobs from the sample have the same workload or have uneven distribution of occupation groups and workloads, then it can affect the outcome of the work relationship and the level of burnout. Swasti, Ekowati, \& Rahmawati (2018) reported contrary results where they found a correlation between occupation and burnout levels, the participants came from more diverse occupations 
such as teacher, lecturer, employee, and health worker which have different workload and qualifications of education level [20]. Correlative result between occupation and burnout level was also found in research conducted by Li, et al. (2021) where people with high occupational stress jobs (for instance a nurse) is more likely to develop higher level of burnout [21]. In other word, correlation between occupation and burnout cannot be found because the sample in this study is dominated by one group occupation which affect to no varieties of workload and occupational stress in the sample.

\section{Conclusion}

The knowledge of young adult participants about burnout and the way to overcome it during WFH increased after the webinar. Most of the participants experienced high and very high levels of burnout. Participants' occupations were not related to burnout levels. Knowledge about efforts to prevent burnout during WFH during a pandemic is very important in improving the productivity and quality of life, especially for young adults. However, broadening the target across different ages and occupations can yield the better results.

\section{Acknowledgments}

We would like to thank to the Coordinator of the Medical Program, Faculty of Medicine, Universitas Airlangga and the lecturer for their contribution to the implementation of the Community Service Program and the preparation of this scientific articles.

\section{References}

[1] WHO, World Health Organization (WHO)., 2021. [Online]. Available: https://www.who.int/indonesia/news/novel-coronavirus/qa/qa-for-public. [Accessed 25 July 2021].

[2] Satuan Tugas Penanganan COVID-19 (Satgas COVID-19), 2021. [Online]. Available: https://covid19.go.id/peta-sebaran. [Accessed 25 July 2021].

[3] V. S. Salian, J. A. Wright, P. T. Vedell, S. Nair, C. Li, M. Kandimalla, X. Tang, E. M. C. Porquera, K. R. Kalari and K. K. Kandimalla, "COVID-19 Transmission, Current Treatment, and Future Therapeutic Strategies.," Molecular Pharmaceutics, vol. 18, no. 3, pp. 754-771, 2021.

[4] Kemenkes, Direktorat Promosi Kesehatan Kementerian Kesehatan RI (Promkes Kemenkes RI) , 2 July 2021. [Online]. Available: https://promkes.kemkes.go.id/infografis-ppkm-darurat-3-20-juli-2021. [Accessed 26 July 2021].

[5] S. Hayes, J. L. Priestley, N. Iishmakhametov and H. E. Ray, "'I'm not Working from Home, I'm Living at Work": Perceived Stress and Work-Related Burnout before and during COVID-19," pp. 1-28, 2020.

[6] D. Queen and K. Harding, "Societal pandemic burnout: A COVID legacy," International Wound Journal, vol. 17, no. 4, pp. 873-874, 2020.

[7] M. FKUI, Fakultas Kedokteran Universitas Indonesia (FKUI), 14 September 2020. [Online]. Available: https://fk.ui.ac.id/berita/83-tenaga-kesehatan-indonesia-mengalami-burnout-syndrome-derajat-sedang-danberat-selama-masa-pandemi-covid-19.html. [Accessed 29 July 2021].

[8] A. M. Karunia and B. P. Jatmiko, 5 June 2020. [Online]. Available: https://money.kompas.com/read/2020/06/05/133207026/survei-ppm-manajemen-80-persen-pekerjamengalami-gejala-stres-karena-khawatir. [Accessed 26 July 2021].

[9] R. Fauziyyah, R. C. Awinda and B. , "Dampak Pembelajaran Jarak Jauh terhadap Tingkat Stres dan Kecemasan Mahasiswa selama Pandemi COVID-19.," Jurnal Biostatistik, Kependudukan, Dan Informatika Kesehatan, vol. 1, no. 2, pp. 113-123, 2021.

[10] A. N. Ramadhania, "Strategi Untuk Mengatasi Serta Mengelola Rasa Stress di Masa Pandemi COVID-19 Bagi Mahasiswa.," pp. 1-6, 2021.

[11] C. Maslach, S. E. Jackson and M. P. Leiter, Maslach Burnout Inventory: Third Edition, vol. 3, Scarecrow Education, 1997, pp. 191-218.

[12] A. F. Purwanto, "Gambaran Burnout Pada Petani Karet PTPN XII Renteng Kecamatan Ajung Kabupaten Jember," Digital Repository Unej, Jember, 2019. 
[13] E. Christiana, "Burnout Akademik Selama Pandemi Covid 19," in Prosiding Seminar Bimbingan dan Konseling, 2020.

[14] J. d. 1. Fuente, M. Pachón-Basallo, F. H. Santos, F. J. Peralta-Sánchez, M. C. González-Torres, R. ArtuchGarde, P. V. Paoloni and M. L. Gaetha, "How Has the COVID-19 Crisis Affected the Academic Stress of University Students? The Role of Teachers and Students," Frontiers in Psychology, 1 June 2021.

[15] S. Zhang, R. Shi, L. Yun, X. Li, Y. Wang, H. He and D. Miao, "Self-regulation and Study-Related Health Outcomes: A Structural Equation Model of Regulatory Mode Orientations, Academic Burnout and Engagement Among University Students," Social Indicators Research, vol. 123, no. 2, pp. 585-599, 1 September 2015.

[16] Tarwoto, R. Aryani, A. Nuraeni, B. Miradwiyana, S. N. Tauchid, S. Aminah, S. D. H. Nurhaeni, A. E. Saprudin and R. Chairani, Kesehatan Remaja Problem dan Solusinya, vol. 1, Jakarta: Salemba Medika, 2010, pp. 1-152.

[17] L. Hanifah and S. Suparti, "Hubungan Usia Dengan Pengetahuan Remaja Putri Tentang Pemeriksaan Payudara Sendiri (SADARI)," Jurnal Kebidanan Indonesia, vol. 8, no. 2, 2017.

[18] R. E. Kapti, Y. Rustina and W. , "Efektifitas Audiovisual Sebagai Media Penyuluhan Kesehatan Terhadap Peningkatan Pengetahuan dan Sikap Ibu Dalam Tatalaksana Balita Dengan Diare di Dua Rumah Sakit Kota Malang," Jurnal Ilmu Keperawatan, vol. 1, no. 1, pp. 53-60, May 2013.

[19] A. Fajriani and D. Septiari, "74| Jurnal Akuntansi, Ekonomi dan Manajemen Bisnis | 2015 Vol. 3(1) 74-79| ISSN: 2337-7887Pengaruh Beban Pekerjaan terhadap Kinerja Karyawan: Efek Mediasi Burnout," Jurnal Akuntansi, Ekonomi dan Manajemen Bisnis, vol. 3, no. 1, pp. 74-79, 2015.

[20] K. G. Swasti, W. Ekowati and E. Rahmawati, "Faktor-Faktor yang Bempengaruhi Burnout Pada Wanita Bekerja di Kabupaten Banyumas," Jurnal Keperawatan Soedirman, vol. 12, no. 3, pp. 190-198, 2018.

[21] X. Li, T. Jiang, J. Sun, L. Shi and J. Liu, "The relationship between occupational stress, job burnout and quality of life among surgical nurses in Xinjiang, China," BMC Nursing, vol. 20, no. 1, pp. 1-11, 2021. 